\title{
Retraction Note: Cognitive deficits in multiple sclerosis: a review of functional MRI studies
}

\author{
Francesca Caramia $\cdot$ E. Tinelli $\cdot$ A. Francia $~$ \\ C. Pozzilli
}

Published online: 15 February 2012

(C) Springer-Verlag 2012

Retraction Note: Neurol Sci (2010) 31 (Suppl 2):S239-S243

DOI 10.1007/s10072-010-0379-1

The article has been retracted upon request of the editor since significant portions of the article were published earlier in the following article: Genova HM, Sumowski JF, Chiaravalloti N, Voelbel GT, Deluca J (2009) Cognition in Multiple Sclerosis: a review of neuropsychological and fMRI research. Front Biosci 14:1730-1744.

The online version of the original article can be found under doi:10.1007/s10072-010-0379-1.

F. Caramia $(\bowtie) \cdot$ E. Tinelli · A. Francia · C. Pozzilli

Department of Neurological Sciences, University of Rome,

“'La Sapienza", Viale dell'Università 30, 00185 Rome, Italy

e-mail: francesca.caramia@uniroma1.it 